\title{
Obesity and underweight among Brazilian elderly. The Bambuí Health and Aging Study
}

\author{
Obesidade e baixo peso entre idosos \\ brasileiros. Projeto Bambuí
}

Sandhi M. Barreto 1,2

Valéria M. A. Passos 1

Maria Fernanda F. Lima-Costa 1,2

\footnotetext{
1 Laboratório de Epidemiologia e Antropologia Médica, Centro de Pesquisas René Rachou, Fundação Oswaldo Cruz. Av. Augusto de Lima 1715, Belo Horizonte, $M G$ 30190-002, Brasil. sbarreto@cpqrr.fiocruz.br lima-costa@cpqrr.fiocruz.br

2 Faculdade de Medicina, Universidade Federal de Minas Gerais. Rua Alfredo Balena 190, Belo Horizonte, $M G$ 30130-100, Brasil.
}

\begin{abstract}
The coexistence of obesity (body mass index, $B M I \geq 30 \mathrm{~kg} / \mathrm{m}^{2}$ ) and underweight (BMI $\leq$ $20 \mathrm{~kg} / \mathrm{m}^{2}$ ) and related factors were investigated among all residents aged 60+ years in Bambuí, Minas Gerais State, using multinomial logistic regression. 1,451 (85.5\%) of the town's elderly participated. Mean BMI was $25.0\left(S D=4.9 \mathrm{~kg} / \mathrm{m}^{2}\right)$ and was higher for women and decreased with age. Prevalence of obesity was 12.5\% and was positively associated with female gender, family income, hypertension, and diabetes and inversely related to physical activity. Underweight affected 14.8\% of participants, increased with age, and was higher among men and low-income families. It was negatively associated with hypertension and diabetes and directly associated with Trypanosoma cruzi infection and $\geq 2$ hospitalizations in the previous 12 months. Both obesity and underweight were associated with increased morbidity. The association of underweight with T. cruzi infection, increased hospitalization, and low family income may reflect illness-related weight loss and social deprivation of elderly in this community. Aging in poverty may lead to an increase in nutritional deficiencies and health-related problems among the elderly.
\end{abstract}

Key words Aging Health; Obesity; Body Mass Index

Resumo A coexistência de obesidade (Índice de Massa Corpórea: $I M C \geq 30 \mathrm{~kg} / \mathrm{m}^{2}$ ) e de baixo peso $\left(I M C \leq 20 \mathrm{~kg} / \mathrm{m}^{2}\right)$ e seus fatores relacionados foram investigados em 1.451 idosos, $85,5 \% \mathrm{da}$ população com 60+ anos residente em Bambuí, Minas Gerais, utilizando-se a análise logística multinomial. O IMC (média $=25,0 ; D P=4,9 \mathrm{~kg} / \mathrm{m}^{2}$ ) foi maior nas mulheres e diminuiu com a idade. A obesidade ocorreu em 12,5\% dos idosos; foi associada positivamente ao sexo feminino, à maior renda familiar e presença de hipertensão e diabete, $e$ inversamente à atividade física. $O$ baixo peso ocorreu em 14,8\% dos idosos, aumentou com a idade, foi maior nos homens e nas famílias com menor renda, esteve inversamente associado à presença de hipertensão e de hiperglicemia e diretamente associado à infecção por Tripanossoma cruzi e duas ou mais internações no último ano. A obesidade e o baixo peso foram ambos associados a uma maior morbidade. A associação do baixo peso com a infecção por T. cruzi, maior hospitalização e menor renda pode estar refletindo a perda de peso secundária a doenças ou à privação social do idoso nesta comunidade. Envelhecer na pobreza pode aumentar as deficiências nutricionais e os problemas de saúde entre idosos.

Palavras-chave Saúde do Idoso; Obesidade; Índice de Massa Corporal 


\section{Introduction}

Epidemiological, demographic, and nutritional transitions are taking place in many developing countries. The elderly population is already the fastest-growing group in Brazil, and increases of up to $300 \%$ in the older population are expected in many developing countries within the next 30 years, especially in Latin America and Asia (Truelsen et al., 2001). Diets and activity patterns are also changing rapidly in most developing countries and problems of obesity and malnutrition are likely to coexist, as are communicable and non-communicable diseases (Darnton-Hill \& Coyne, 1998), especially in countries with great socioeconomic disparities such as Brazil. In fact, the concomitance of malnutrition and obesity has been reported in a very low-income population in Northeast Brazil (Florêncio et al., 2001). In addition, a worrisome increase in the prevalence of obesity has been observed in three Brazilian surveys conducted between 1973 and 1996 (Lotufo, 2000).

Epidemiological studies on nutrition in the elderly indicate that both overweight and underweight measured by body mass index (BMI) are associated with greater risk of morbidity and mortality (Vellas et al., 1997). Overall, the relationship between BMI and all-cause mortality has been described as U- or J-shaped (Vellas et al., 1997; Visscher et al., 2000; WHO, 1998). Epidemiological studies of minimal mortality points in relation to BMI in developed countries suggest that the "best" BMI (the nadir in the "U-curve") gradually increases with age in both genders, with no consistent differences between men and women (Visscher et al., 2000).

Despite being an important predictor of morbidity and mortality in seniors, little is known about the anthropometry of aging and possible weight-related health conditions among the elderly in a context of epidemiological transition. This study describes the distribution of BMI among the elderly in a community and investigates the association of obesity and underweight with selected health conditions and socioeconomic differences in this group.

\section{Methods}

The present study analyzes the baseline data of the Bambuí Health and Aging Study (BHAS), a population-based cohort study of older adults (60+ years) in Brazil (Lima-Costa et al., 2000).

The study involved the elderly population living in Bambuí town, Minas Gerais State,
Southeast Brazil. The municipality of Bambuí had some 15,000 inhabitants in the urban area (or Bambuí town proper) in 1991. Bambuí was formerly an important endemic area for Chagas disease. Even though transmission of Trypanosoma cruzi was interrupted around 20 years ago, prevalence of the infection remains high among the elderly (38\%) because of a cohort effect (Lima-Costa et al., 2002). The main causes of death in this municipality in 1996 were stroke, Chagas disease, ischemic heart disease, and chronic obstructive pulmonary disease (Lima-Costa et al., 2000).

A complete census was conducted in Bambuí town in November and December 1996 for the identification of elderly participants in the baseline cohort study. All residents aged 60+ years $(n=1,742)$ were selected for interviews and examination (blood tests and anthropometric and blood pressure measurements) (Lima-Costa et al., 2000).

The following variables from the baseline interview were included in this study: (1) sociodemographic characteristics (age, gender, marital status, schooling, and monthly income); (2) lifestyle (current smoking status and physical activity); (3) self-rated health in the previous 6 months; (4) health services indicators (doctor visits in past 12 months and hospitalizations in past 12 months). Monthly family income was reported as "number of times the prevailing Brazilian monthly minimum wage" (approximately US\$100).

When an elderly participant could not be interviewed because of cognitive deficit or for some other health reason, an appropriate proxy was used. Proxy respondents were not asked personal questions that required a subjective statement.

Anthropometric measures were performed by specially trained health technicians, using standard equipment, with individuals wearing light clothing and no shoes. Weight (kg), height $(\mathrm{cm})$, waist circumference $(\mathrm{cm})$, and hip circumference $(\mathrm{cm})$ were measured with individuals wearing light clothing. The reliability of these measurements was ascertained repeating them in a $5 \%$ sample of all participants. Two high-precision digital scales (range 0-150kg x $0.1 \mathrm{~kg}$ ) and a CMS Portable Stadiometer kit (CMS Weighing Equipment Ltd., London) were employed for anthropometric measurements.

Blood pressure (BP) was measured 30 or more minutes after the last caffeine intake or cigarette smoked. Three measurements were taken after 5 minutes of initial rest and subsequently at 2-minute intervals. BP was defined as the arithmetic mean of the second and third 
measurements. Hypertension was defined as diastolic blood pressure (DBP) $\geq 90 \mathrm{mmHg}$ and/or systolic blood pressure (SBP) $\geq 140 \mathrm{mmHg}$ and/ or current use of antihypertensive medication at the time of interview (JNC, 1993). Further details have been published elsewhere (Barreto et al., 2001).

Blood samples were collected after 12-hour fasting. Plasma glucose levels were determined using an automated analyzer (Eclipse Vitalab, Merck, Netherlands). Diabetes was defined as fasting blood glucose $\geq 126 \mathrm{mg} / \mathrm{dl}$ and / or current use of hypoglycemic medication. Hematological tests were performed with an electronic counter (Coulter Counter T890, United States). Anemia was defined as hemoglobin levels $<12 \mathrm{mg} \%$ for women and < $13 \mathrm{mg} \%$ for men (Tietz et al., 1992). The presence of T. cruzi antibodies was detected using an indirect hemagglutination test and an enzyme-linked immunosorbent assay (Biolab and Abbott Brazil, respectively). T. cruzi infection was defined when the serum samples showed positive results in both serological tests.

Descriptive statistics were used to fully explore the data. One sample t-test was used for comparisons between means and designedbased Pearson chi-square test for proportions. Since we lack population-based weight and height parameters for Brazilian elderly, and because there is no consensus in the literature with respect to the definition of underweight for elderly (Heiat et al., 2001; Inelmen et al., 2000; Murasco \& Bernstein, 1998), we defined underweight and obesity as the mean body mass index $(\mathrm{BMI}=$ weight $/$ height squared $) \pm$ one standard deviation. In this community these cut-off values were 20 and $30 \mathrm{~kg} / \mathrm{m}^{2}$, respectively.

Because the dependent variable is composed of three categories (BMI $\leq 20, \mathrm{BMI} \geq 30$, and $20>\mathrm{BMI}<30 \mathrm{~kg} / \mathrm{m}^{2}$ ), we employed multinomial logistic regression techniques to estimate the association of BMI with independent variables (Hamilton, 1993). BMI over 20 and less than $30 \mathrm{~kg} / \mathrm{m}^{2}$ was taken as the reference category. The analysis was carried out using the Stata statistical software.

This study was conducted according to the Helsinki Declaration and approved by the Ethics Committee of the Oswaldo Cruz Foundation. Participation was voluntary, and a signed informed consent form was obtained. Interviews, physical measurements, and blood tests were conducted from January to August 1997(LimaCosta et al., 2000).

\section{Results}

From a total of 1,742 residents aged $60+$ years, $1,443(83.1 \%)$ participated in this study. Table 1 shows the BMI $\left(\mathrm{kg} / \mathrm{m}^{2}\right)$ distribution for men and women by age group. Mean total BMI was $25.0 \mathrm{~kg} / \mathrm{m}^{2}(\mathrm{SD}=4.9)$, was lower for males than females, and decreased significantly with age. A total of $208(14.4 \%)$ individuals were underweight $\left(\mathrm{BMI} \leq 20 \mathrm{~kg} / \mathrm{m}^{2}\right)$ and 185 (12.8\%) were obese (BMI $\left.\geq 30 \mathrm{~kg} / \mathrm{m}^{2}\right)$.

Figure 1 shows the prevalence of underweight and obesity according to age group for men and women. Mean BMI was $18.1 \mathrm{~kg} / \mathrm{m}^{2}$ (95\% CI: $17.8-18.4 \mathrm{~kg} / \mathrm{m}^{2}$ ) among individuals with underweight, $34.0 \mathrm{~kg} / \mathrm{m}^{2}$ (95\% CI: 33.4 $34.6 \mathrm{~kg} / \mathrm{m}^{2}$ ) among those overweight, and $25.2 \mathrm{~kg} / \mathrm{m}^{2}$ (95\% CI: $25.0-25.4$ ) in the reference category. Waist to hips ratio (WHR) increased with BMI, with 0.89 (95\% CI: 0.88-0.90) in the lower BMI category, 0.93 (95\% CI: 0.93-0.94) for the reference category, and 0.94 (95\% CI: 0.930.95 ) among obese individuals, with no significant difference between the latter group and the reference category.

Obesity was more common among women, and prevalence decreased with age, but this decrease was only statistically significant among women. Unlike underweight, the initial analysis shows that obesity was more common among individuals with higher income and educational levels. Age-adjusted OR of obesity were 2.39 (95\% CI: 1.38-4.16) for individuals with monthly income $\geq 6$ times the Brazilian minimum wage ( \pm US\$600) and 3.02 (95\% CI: 1.69-5.4) for those with 8+ years of schooling.

Underweight was significantly more common among men than women and increased

\begin{tabular}{|c|c|c|}
\hline \multicolumn{3}{|c|}{$\begin{array}{l}\text { Distribution of body mass index }\left(\mathrm{kg} / \mathrm{m}^{2}\right) \text { in community } \\
\text { elderly by age group and sex. BHAS, } 1997 \text {. }\end{array}$} \\
\hline \multirow[t]{2}{*}{ Age group } & \multicolumn{2}{|c|}{ Body mass index $\left(\mathrm{kg} / \mathrm{m}^{2}\right)$} \\
\hline & Mean (SD) & Median (range) \\
\hline \multicolumn{3}{|l|}{ Men } \\
\hline 60-69 & $24.4(3.8)$ & $24.3(16.1-40.5)$ \\
\hline $70-79$ & $23.3(4.4)$ & $22.7(15.5-44.3)$ \\
\hline $80+$ & $22.5(3.7)$ & $22.6(15.7-30.2)$ \\
\hline \multicolumn{3}{|l|}{ Women } \\
\hline 60-69 & $26.2(5.3)$ & $25.9(14.6-53.6)$ \\
\hline $70-79$ & $25.6(5.0)$ & $25.6(12.4-42.8)$ \\
\hline $80+$ & $23.8(4.8)$ & $23.0(16.3-46.5)$ \\
\hline
\end{tabular}


Figure 1

Prevalence of underweight and obesity among older adults by gender and age group. BHAS, 1997.
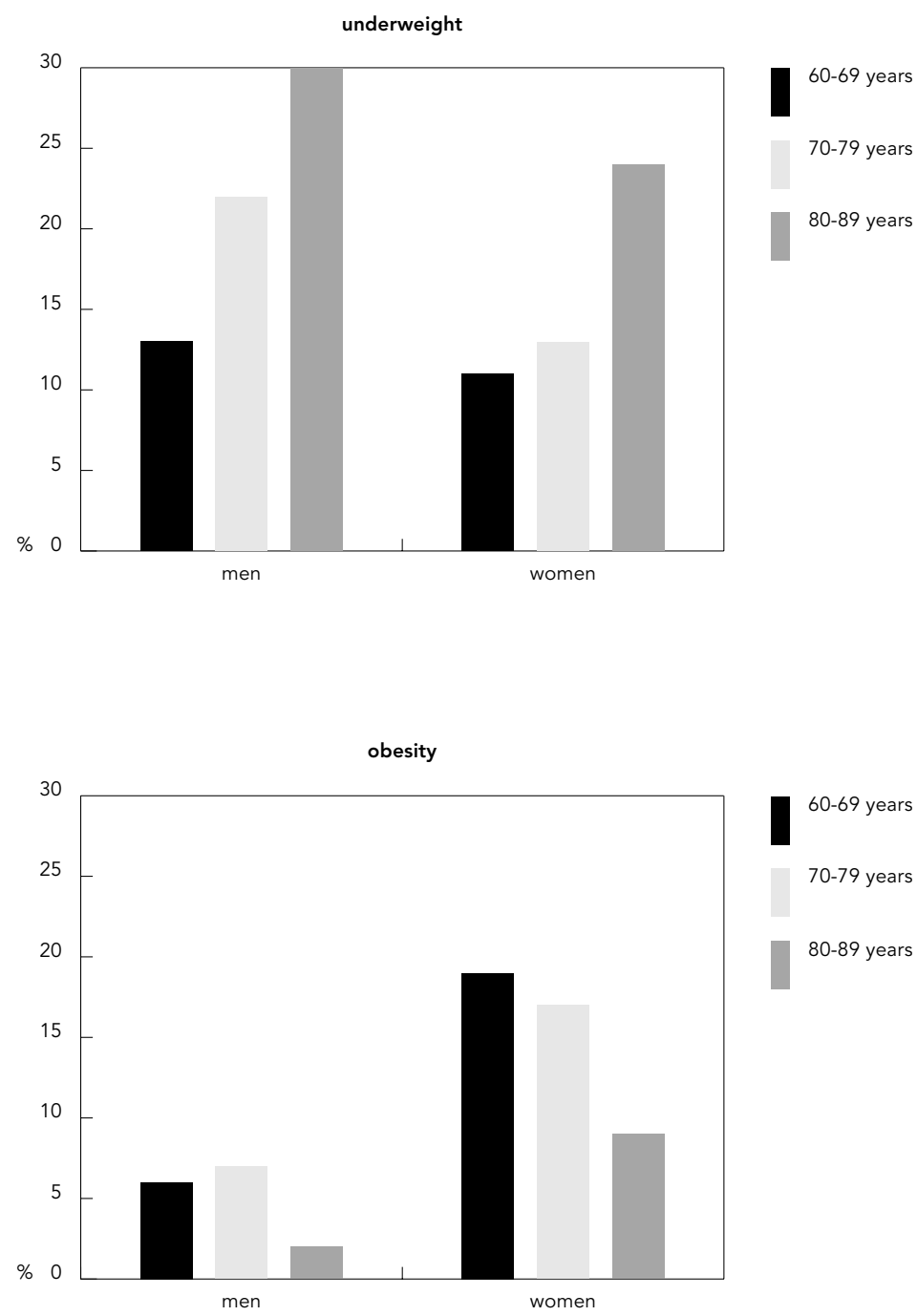

directly with age in both genders. There was a highly statistically significant declining trend in the age- and sex-adjusted prevalence of underweight with increasing income and schooling: OR of 0.50 (0.31-0.82), 0.31 (0.13-0.74), and $0.28(0.12-0.66)$ for monthly family income equal to $2-3.9,4-5.9$, and $\geq 6$ times the Brazilian minimum wage and OR equal to $0.60(0.42-0.86)$, 0.54 (0.37-0.79), and $0.15(0.06-0.45)$ for zero, $1-3,4-7$, and $8+$ years of schooling, respectively.

Since income and schooling are highly correlated $\left(\chi^{2}=327 ; \mathrm{p}<0.001\right)$ and data on income were missing for a few participants, only school- ing was entered in the multivariate analysis. There were no significant gender differences in the direction and magnitude of the associations of obesity and underweight with the factors presented in Table 2 and 3. Therefore, the results of the multivariate analysis are presented jointly for men and women and adjusted for gender.

Table 2 shows the results of the multivariate analysis of underweight and obesity in relation to social-demographic characteristics, lifestyle factors, and selected health conditions. Obesity was positively and significantly associated with physical inactivity, hypertension, and diabetes and negatively associated with anemia. Underweight was inversely and significantly associated with hypertension and diabetes. It was much more frequent among smokers and especially among former smokers, as well as those with $T$. cruzi infection and with anemia.

Analysis of health perception and health care use (Table 3 ) shows that obese individuals tend to self-rate their health worse than those in the reference BMI category, but this difference was not statistically significant for underweight individuals. It also shows that underweight individuals report more hospitalizations in the previous 12 months, while obese persons reported more doctor visits during the previous year.

\section{Discussion}

We found a considerable prevalence of obesity and underweight in this community, with a slightly greater preponderance of the latter. Age and gender characteristics associated with both obesity and underweight in our study are consistent with results from other studies (Ostbye et al., 1995; Visscher et al., 2000).

Obesity is a growing problem even in developing regions like ours. It varies greatly between countries and is more common in females and in urban populations. In this community the prevalence of obesity is closer to that found among adults in Europe (Seidell \& Flegal, 1997) and in India (Zargar et al., 2000). However, unlike many developed countries, in this elderly community obesity was more common among non-poor as compared to poor individuals (James et al., 1997; Michaud et al., 1998). The combination of obesity with better socioeconomic condition has also been described in other studies in Brazil (Monteiro et al., 2002; Sichieri et al., 1994) and in other developing countries. In China and India, higher 


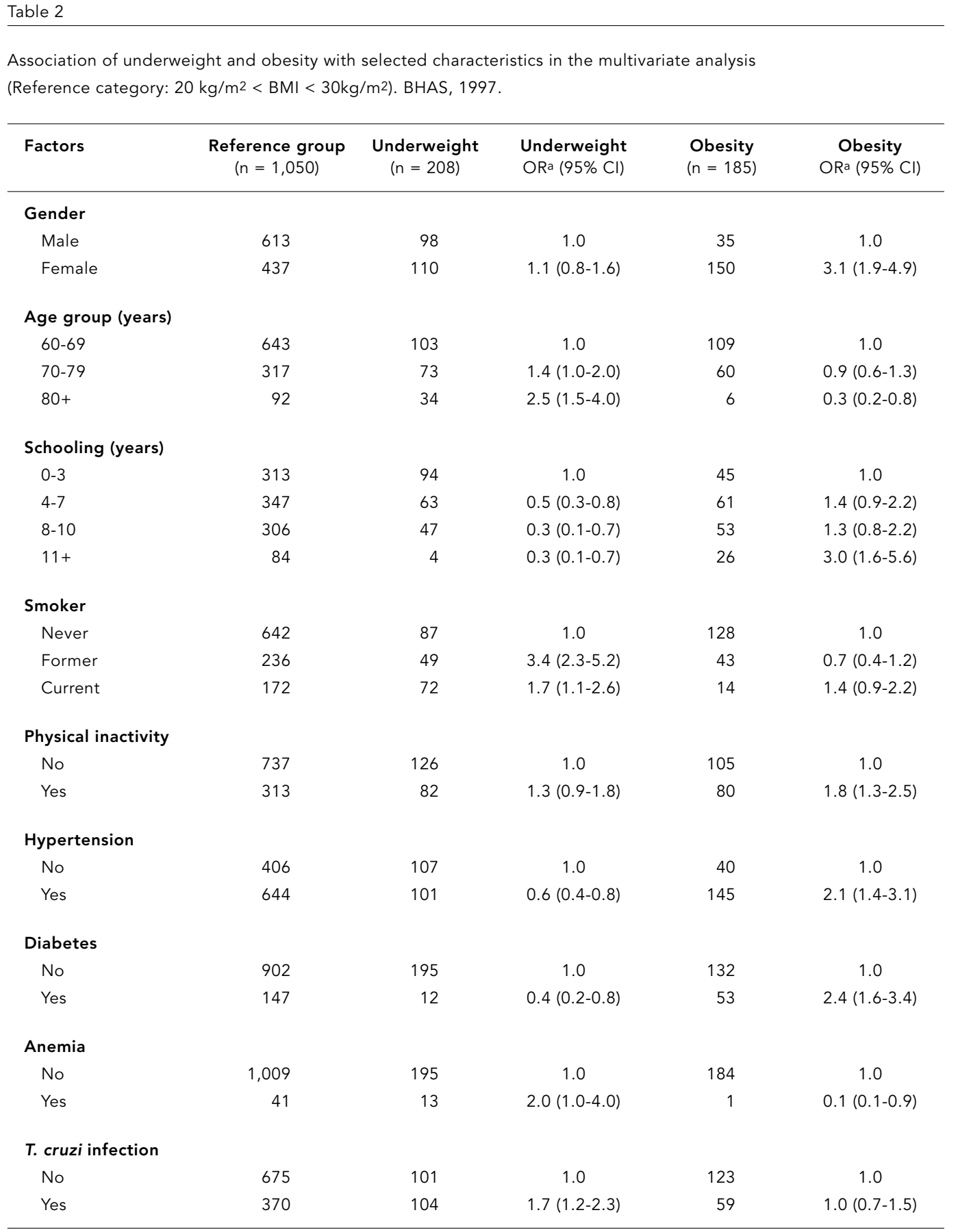

a Odds ratios simultaneously adjusted for all factors in the table.

income levels, particularly in urban areas, were also associated with consumption of a more fat-rich diet and with problems of obesity (Mehta \& Shingarpure, 2000; Popkin et al., 1993). Excess weight seems to appear first among the affluent and then among low-income classes. The main causes appear to be a nutritional transition to lipid-rich diets combined with reduced physical activity.
Our results show that obesity is positively associated with hypertension and diabetes. Obesity is a complex metabolic disorder frequently associated with insulin resistance, hyperinsulinemia, accelerated atherosclerosis, hypertension, and type II diabetes (Solomon \& Manson, 1997). The association between obesity and inactivity has also been described in other studies. Actually, decreased level of over- 
Association of underweight and obesity with health perception and health care use selected in the multivariate analysis. BHAS, 1997

\begin{tabular}{|c|c|c|c|c|c|}
\hline Factors & $\begin{array}{c}\text { Reference group } \\
(\mathrm{n})\end{array}$ & $\begin{array}{l}\text { Underweight } \\
\text { (n) }\end{array}$ & $\begin{array}{l}\text { Underweight } \\
\text { ORa }(95 \% \mathrm{Cl})\end{array}$ & $\begin{array}{l}\text { Obesity } \\
\text { (n) }\end{array}$ & $\begin{array}{c}\text { Obesity } \\
\text { ORa }(95 \% \mathrm{Cl})\end{array}$ \\
\hline \multicolumn{6}{|l|}{$\begin{array}{l}\text { Visits to doctor } \\
\text { in past } 12 \text { months }\end{array}$} \\
\hline None & 226 & 40 & 1.0 & 19 & 1.0 \\
\hline 1 & 234 & 41 & $1.0(0.6-1.6)$ & 36 & $1.4(0.8-2.6)$ \\
\hline $2+$ & 590 & 127 & $1.0(0.6-1.5)$ & 130 & $1.8(1.1-3.1)$ \\
\hline \multicolumn{6}{|l|}{$\begin{array}{l}\text { Hospitalization } \\
\text { in past } 12 \text { months }\end{array}$} \\
\hline None & 852 & 144 & 1.0 & 146 & 1.0 \\
\hline 1 & 147 & 37 & $1.4(0.9-2.1)$ & 27 & $0.8(0.5-2.2)$ \\
\hline $2+$ & 51 & 27 & $2.4(1.4-4.2)$ & 12 & $1.1(0.6-2.2)$ \\
\hline \multicolumn{6}{|l|}{$\begin{array}{l}\text { Self-rated health } \\
\text { in past six month }\end{array}$} \\
\hline Very good/good & 279 & 40 & 1.0 & 39 & 1.0 \\
\hline Fair & 524 & 98 & $1.2(0.8-1.8)$ & 91 & $1.7(1.2-2.5)$ \\
\hline Poor/very poor & 247 & 91 & $1.5(1.0-2.4)$ & 55 & $1.1(1.1-2.8)$ \\
\hline
\end{tabular}

a Odds ratios adjusted for all factors in the table, plus age, gender, and schooling.

all physical activity is a major contributor to the rise in overweight and obesity rates. According to a report from the WHO (1998), lack of exercise and obesity contribute to up to one third of colon, breast, kidney, and digestivetract cancers. However, the relative risk of death associated with excess adiposity appears to be less for older than for younger and middleaged adults (Heiat et al., 2001; Stevens et al., 1999). Actually, epidemiological studies do not support overweight $\left(\mathrm{BMI}=25-29 \mathrm{~kg} / \mathrm{m}^{2}\right)$, as opposed to obesity ( $\geq 30 \mathrm{~kg} / \mathrm{m}^{2}$ ), as conferring an excess mortality risk to the elderly (Heiat et al., 2001; Reynolds et al., 1999).

Obese elderly reported more doctor visits and perceived their health worse than those in the normal weight range. It has been observed that obese people tend to have more health problems and rate their health as fair or poor (Ostbye et al., 1995). Perhaps these two factors express the same feeling of poor health and a tendency of modern society to indistinctly condemn overweight.

While obesity was more common among families earning around US\$600 or more per month, the prevalence of underweight increased inversely with monthly family income, with a highly significant linear trend. Malnutrition is a serious threat to elderly life because it can lead to lower physical strength, greater in- activity, higher risk of accidents, and a weakened immune system, among other health problems (Chandra, 1992; James et al., 1997).

The increased number of hospitalizations among underweight individuals may be an indicator of worse health conditions in this group. Nutritional deficiencies, frequently observed among the frail elderly, have been associated with increased morbidity and dependency. Protein-energy malnutrition appears to be a strong independent risk factor for nonelective hospital readmission, especially among the highest-risk patients, those who are functionally independent and cognitively intact (Sullivan, 1992). It has been argued that the inverse association of weight and mortality in old age is related to smoking and reflects illnessrelated weight loss. In a longitudinal study, elderly women with lower energy intake than recommended by international organizations in 1980 were three times more likely to die in 10 years than those with satisfactory energy intake (Vellas et al., 1997).

The heterogeneity of the elderly population and the high prevalence of chronic and infectious diseases may affect (and be affected) by the nutritional status of the population and deserves further investigation. In this Brazilian community, the burden of Chagas disease was particularly great for the elderly (Lima-Costa, 
2002), and the increased association of T. cruzi infection with underweight suggests that this group is significantly more affected by this important health problem.

The cut-points that we used to define underweight and obesity may be conservative. A meta-analysis of the relationship between body weight and all-cause mortality has identified an increased risk of death among older adults with BMI $<23$ or $>28 \mathrm{~kg} / \mathrm{m}^{2}$ (Troiano et al., 1996). With these references, the prevalence of underweight in this community would increase to $35.0 \%$ and of obesity to $24.8 \%$, with underweight being more prevalent among individuals with T. cruzi infection $(43.1 \%$ vs. $30.2 \%$, p < 0.001).

In this study we found an inverse association between BMI and education and income, unlike reports from developed countries (Ostbye et al., 1995; Seidell \& Flegal, 1997). A simi-

\section{Acknowledgements}

The authors wish to thank the following contributors to the Bambuí Health and Aging Study Group (BHAS): J. O. A. Firmo, E. Uchoa, H. L. Guerra, and P. G. Vidigal. We thank all the individuals enrolled in the BHAS who gave free and informed consent before participating in the study. Research supported by FINEP. S. M. Barreto and M. F. F. Lima-Costa are fellows of the Brazilian National Research Council (CNPq). lar inverse association was also reported in India and appears to express the huge socioeconomic disparities existing in most developing countries (Zargar et al., 2000). The economic gap between the rich and poor nations is growing. Meanwhile, income disparity is growing within most countries, especially among developing ones (Darnton-Hill \& Coyne, 1998). Brazil is one of the countries with the greatest socioeconomic inequalities in the world. Over 50 million Brazilians live below the poverty line (Barros et al., 1999). Elderly people are particularly vulnerable to malnutrition. Even considering that aging is an uneven process, occurring more rapidly among the rich than the poor, the coexistence of aging with poverty might lead to an increase in nutritional deficiencies and health-related problems among the elderly.

\section{References}

BARRETO, S. M.; PASSOS, V. M. A.; FIRMO, J. O. A.; VIDIGAL, P. G. \& LIMA-COSTA, M. F. F., 2001. Hypertension and clustering of cardiovascular risk factors in a community in Southeast Brazil - The Bambuí Health and Ageing Study. Arquivos Brasileiros de Cardiologia, 77:576-581.

BARROS, P. R.; HENRIQUES, R. \& MENDONÇA, R., 1999. A Estabilidade Inaceitável: Desigualdade e Pobreza no Brasil. Texto para Discussão 800. Rio de Janeiro: Instituto de Pesquisa Econômica Aplicada.

CHANDRA, R. K., 1992. Nutrition and immunoregulation. Significance for host resistance to tumours and infectious diseases in humans and rodents. Journal of Nutrition, 122(Sup.):754-757.

DARNTON-HILL, I. \& COYNE, E. T., 1998. Feast and famine: Socio-economic disparities in global nutrition and health. Public Health Nutrition, 1:2331.

FLORÊNCIO, T M.; FERREIRA, H. S.; FRANCA, A. P.; CAVALCANTE, J. C. \& SAWAYA, A. L., 2001. Obesity and undernutrition in a very low-income population in the city of Maceió, Northeastern Brazil. Brazilian Journal of Nutrition, 86:277-284. 
HAMILTON, L. C., 1993. Interpreting multinomial logistic regression. Stata Technical Bulletin, 13:2428.

HEIAT, A.; VACCARINO, V. \& KRUMHOLS, H. M., 2001. An evidence-based assessment of Federal Guidelines for overweight and obesity as they apply to elderly persons. Archives of Internal Medicine, 161:1194-1203.

INELMEN, E. M.; GIMENEZ, G. F.; GATTO, M. R.; MIOTTO, F.; SERGI, G.; MARCCARI, T.; GONZALEZ, A. M.; MAGGI, S.; PERUZZA, S.; PISENT, C. \& ENZI, G., 2000. Dietary intake and nutritional status in Italian elderly subjects. Journal of Nutrition, Health \& Aging, 4:91-101.

JAMES, W. P.; NELSON, M.; RALPH, A. \& LEATHER, S., 1997. Socio-economic determinants of health. The contribution of inequalities in health. BMJ, 314:1545-1549.

JNC (Joint National Committee), 1993. The fifth report of the Joint National Committee on Detection, Evaluation, and Treatment of High BP. Archives of Internal Medicine, 153:154-183.

LIMA-COSTA, M. F. F.; BARRETO, S. M.; GUERRA, H. L.; FIRMO, J. O. A.; UCHOA, E. \& VIDIGAL, P. G., 2002. Ageing with Trypanosoma cruzi infection in a community where the transmission has been interrupted: The Bambuí Health and Ageing Study (BHAS). International Journal of Epidemiology, 30:887-893.

LIMA-COSTA, M. F. F; UCHÔA, E.; GUERRA, H. L.; FIRMO, J. O. A.; VIDIGAL, P. G. \& BARRETO, S. M., 2000. The Bambuí Health and Ageing Study (BHAS). Methodological approach and preliminary results of a population-based cohort study of the elderly in Brazil. Revista de Saúde Pública, 34:126-135.

LOTUFO, P. A., 2000. Increasing obesity in Brazil: Predicting a new peak of cardiovascular mortality. São Paulo Medical Journal, 118:161-162.

MEHTA, P. \& SHRINGARPURE, B., 2000. Diet nutrition and health profile of elderly population of urban Baroda. Indian Journal of Public Health, 44:124-128.

MICHAUD, C.; BAUDIER, F.; LONDOU, A.; LE BEHIAN, G.; JANVRIN, M. P. \& ROTILY, M., 1998. Food habits, consumption and knowledge of a low income French population. Santé Publique, 10:333347.

MONTEIRO, C. A.; CONDE, W. L. \& POPKIN, B. M., 2001. Independent effects of income and education on the risks of obesity in the Brazilian adult population. Journal of Nutrition, 131:881S-886S.

MURASCO, D. M. \& BERNSTEIN, E. D., 1998. Nutrition and Aging. In: Principles of Geriatric Medicine and Gerontology (W. R. Hazzard, J. P. Blass, W. H. Ettinger Jr., J. B. Halter \& J. G. Ouslander, ed.), pp. 81-116, 4th Ed., New York: McGraw-Hill.

OSTBYE, T.; POMERLEAU, J.; SPEECHLEY, M.; PEDERSON, L. L. \& SPEECHLEY, K. N., 1995. Correlates of body mass index in the 1990 Ontario Health Survey. Canadian Medical Association Journal, 152:811-817.

POPKIN, B. M.; KEYOU, G.; ZHAI, F.; GUO, X.; MA, H. \& ZOHOORI, N., 1993. The nutrition transition in China: A cross-sectional analysis. European Journal of Clinical Nutrition, 47:333-346.
REYNOLDS, M. W.; FREDMAN, L.; LANGENBERG, P. \& MAGAZINER, J., 1999. Weight, weight change, mortality in a random sample of older community-dwelling womwn. Journal of the American Geriatrics Society, 47:1409-1414.

SEIDELL, J. C. \& FLEGAL, K. M., 1997. Assessing obesity: Classification and epidemiology. British Medical Bulletin, 53:238-252

SICHIERI, R.; COITINHO, D. C.; LEAO, M. M.; RECINE, E. \& EVERHART, J. E., 1994. High temporal, geographic and income variation in body mass index among adults in Brazil. American Journal of Public Health, 84:793-798.

SOLOMON, C. G. \& MANSON, J. E., 1997. Obesity and mortality: A review of the epidemiologic data. American Journal of Clinical Nutrition, 66(Sup. 4):1044S-1050S.

STEVENS, J.; CAI, J.; JUHAERI, M.; THUN, M. J.; WILLIAMSON, D. F. \& WOOD, J. L., 1999. Consequence of the use of different measures of effect to determine the impact of age on the association between obesity and mortality. American Journal of Epidemiology, 150:399-407.

SULLIVAN, D. H., 1992. Risk factors for early hospital readmission in a select population of geriatric rehabilitation patients: The significance of nutritional status. Journal of the American Geriatric Society, 40:792-798.

TIETZ, N. W.; SHUEY, D. F. \& WEKSTEINS, D. R., 1992. Laboratory values in fit aging individual - Sexagenarians through centenarians. Clinical Chemistry, 38:1167-1185.

TROIANO, R. P.; FRONGILLO Jr., E. A.; SOBAL, J. \& LEVITSKY, D. A., 1996. The relationship between body weight and mortality: A quantitative analysis of combined information from existing studies. International Journal of Obesity and Related Metabolic Disorders, 20:63-75.

TRUELSEN, T.; BONITA, R. \& JAMROZIK, K., 2001. Surveillance of stroke: A global perspective. International Journal of Epidemiology, 30:S11-S16.

VELLAS, B. J.; HUNT, W. C.; ROMERO, L. J.; KOEHLER, K. M.; BAUMGARTNER, R. N. \& GARRU, P. J., 1997. Changes in nutritional status and patterns of morbidity among free-living elderly persons: A 10-year longitudinal study. Nutrition, 13:515-519.

VISSCHER, T. L.; SEIDELL, J. C.; MENOTTI, A.; BLACKBURN, H.; NISSINEN, A. \& FESKENS, E. J. \& KROMHOUT, D., 2000. Underweight and overweight in relation to mortality among men aged 40-59 and 50-69 years: The seven countries study. American Journal of Epidemiology, 151:660-666.

WHO (World Health Organization), 1998. Population Ageing: A Public Health Challenge. Geneva: WHO.

ZARGAR, A. H.; MASOODI, S. R.; LAWAY, B. A.; KHAN, A. K.; WANI, A. I.; BASHIR, M. I. \& AKHTAR, S., 2000. Prevalence of obesity in adults - An epidemiological study from Kashmir Valley of Indian Subcontinent. Journal of the Association of Physicians of India, 48:1170-1174.

Submitted on June 132002

Final version resubmitted on October 182002

Approved on January 162003 